\title{
SENSITIVITY PROFILE OF RHIPICEPHALUS (BOOPHILUS) MICROPLUS TICKS OF DAIRY CATTLE TO ACARICIDES IN SMALL FARMS IN THE NORTHWESTERN SÃO PAULO STATE, BRAZIL
}

\author{
T.E.H. Ueno ${ }^{1}$, E.E.B. Mendes ${ }^{1}$, S.H.K. Pomaro ${ }^{2}$, C.K.P. Lima ${ }^{3}$, A.G.A. Guilloux ${ }^{4}$, M.C. Mendes ${ }^{3}$
}

${ }^{1}$ Polo Centro Norte, Unidade de Pesquisa e Desenvolvimento de São José do Rio Preto, Rod. Washington Luiz, km 445, CEP 15025-990, São José do Rio Preto, SP, Brasil. E-mail: tatianaueno@apta.sp.gov.br

\begin{abstract}
Rhipicephalus (Boophilus) microplus tick is one of the most important parasite afflicting cattle, mainly in taurine breed. Chemical application is still the most widely used way of control, although there are reports of tick resisting to many active principles in different countries. The goal of this study was to obtain the in vitro sensitivity profile of dairy cattle ticks to six commercial acaricides in five small farms in northwestern São Paulo state, located in Bady Bassitt and Ipiguá municipalities, and to investigate the productive characteristics and tick control methods applied in these farms. R. (B.) microplus engorged females were collected from naturally infested cattle and subjected to adult immersion test using the following drugs: amitraz, cypermethrin, deltamethrin, chlorpyrifos/ cypermethrin mix, dichlorvos/cypermethrin mix, and dichlorvos/chlorpyrifos mix. In each farm, a questionnaire was also administered. Considering the mean efficacy level from all farms, there was no product with appropriate efficacy level. Pyrethroids had the worst results (cypermethrin and deltamethrin having mean efficacy of $17 \%$ and $27 \%$ respectively), with resistance observed in all farms. Conversely, amitraz (73\%), chlorpyrifos/cypermethrin (79\%), and chlorpyrifos/dichlor$\operatorname{vos}(76 \%)$ exhibited the highest mean efficacies. The ticks were resistant to all formulations in two herds. The cattle farmers were not aware of tests that detect ticks susceptibility to acaricides and did not adopt proper technical procedure when using chemicals. These indicate the need to educate cattle farmers on considering resistance as a product choice criterion. A constant monitoring of resistance is also relevant. Further investigations in the region should be conducted to better understand the resistance levels.
\end{abstract}

KEY WORDS: Ticks, Rhipicephalus (Boophilus) microplus, cattle, resistance, São Paulo.

\section{RESUMO}

PERFILDESENSIBILIDADEDECARRAPATOSRHIPICEPHALUS (BOOPHILUS) MICROPLUS DE BOVINOS LEITEIROS A CARRAPATICIDAS EM PEQUENAS PROPRIEDADES DO NOROESTE DO ESTADO DE SÃO PAULO. O carrapato Rhipicephalus (Boophilus) microplus é um dos parasitos mais importantes em bovinos, principalmente nos de raça taurina. Ocontrolequímico ainda é a forma mais utilizada para o seu controle, porém, há relatos de resistência dos carrapatos a vários princípios ativos em diversos países. O presente trabalho objetivou obter o perfil de sensibilidade in vitro de carrapatos de bovinos leiteiros a seis carrapaticidas comerciais em cinco propriedades do noroeste paulista, localizadas nos municípios de Bady Bassitt e Ipiguá, além de investigar as características produtivas e métodos de controle de carrapatos empregados nestas propriedades. Fêmeas ingurgitadas de $R$. (B.) microplus foram coletadas de bovinos naturalmente infestados e submetidas ao teste de imersão de adultas frente aos seguintes princípios ativos: amitraz, cipermetrina, deltametrina, associação clorpirifós/cipermetrina, associação diclorvós/ cipermetrina e associação diclorvós/clorpirifós. Em cada propriedade, também foi aplicado um questionário. Considerando-se a eficácia média entre todas as propriedades, nenhum produto mostrou eficácia desejável. Os piretroides obtiveram os piores resultados (eficácias médias de $17 \%$ e $27 \%$, respectivamente, para cipermetrina e deltametrina), sendo que em todas as propriedades havia resistência. Já amitraz (73\%), clorpirifós/cipermetrina (79\%) e clorpirifós/diclorvós (76\%) mostraram as maiores eficácias médias. Em dois rebanhos os carrapatos foram resistentes a todas

${ }^{2}$ Coordenadoria de Assistência Técnica Integral, Campinas, SP, Brasil.

${ }^{3}$ Instituto Biológico, Centro de Pesquisa e Desenvolvimento de Sanidade Animal, São Paulo, SP, Brasil.

${ }^{4}$ Universidade de São Paulo, Faculdade de Medicina Veterinária e Zootecnia, São Paulo, SP, Brasil. 
as formulações. Os produtores não conheciam o biocarrapaticidograma e aplicavam carrapaticidas sem critério técnico. Os resultados mostram a necessidade de orientação aos produtores quanto à utilização do biocarrapaticidograma como critério para escolha do acaricida. Um monitoramento constante da resistência também é relevante. Outros estudos na região devem ser feitos para melhor caracterização do nível de resistência.

PALAVRAS-CHAVE: Carrapato, Rhipicephalus (Boophilus) microplus, bovino, resistência, São Paulo.

\section{INTRODUCTION}

The Rhipicephalus (Boophilus) microplus tick is one of the most important parasites of cattle in tropical and subtropical regions of the world, and it is present in America, Africa, Asia and Australia (LeAl et al., 2003). The damage to the animal health is caused by direct action of the tick or by transmission of etiologic agents of diseases, among which stands out Babesia bigemina, Babesia bovis and Anaplasma marginale (PEREIRA et al., 2008).

Economic losses related to the parasite are the decrease in the production of meat and milk, leather damage, costs of tick control (labor, equipment, facilities, acaricides) and loss or treatment of animals with tick-borne diseases (LEAL et al., 2003). GRISI et al. (2002) estimated that the direct and indirect losses could exceed $\$ 2$ billion per year in Brazil.

The application of chemicals is still the most effective method of ticks control (LEAL et al., 2003). The first chemicals systematically used were arsenic compounds in the nineteenth-century. Along time, organochlorines, organophosphates, carbamates, synthetic pyrethroids and amitraz have been used sequentially. Recently, the avermectins, growth regulators, fipronil and spinosad were introduced (George, 2000; Pereira et al., 2008). However, uncontrolled applications of commercial acaricides may have accelerated the emergence of ticks resistance to several active ingredients available (PEREIRA et al., 2008). In Brazil, resistance to chemicals has been observed in many states, such as Bahia (BA) (CAmpos Junior; Oliveira, 2005), Minas Gerais (MG) (ARANTEs et al., 1995; Leite et al., 1995), Paraná (PR) (Merlini; Yamamura, 1998), Rio Grande do Sul (RS) (CAmillo et al., 2009) and São Paulo (SP) (MENDEs et al., 2001; PereIRA, 2006).

The aim of the present work was to evaluate the in vitro efficacy of six commercial acaricides on $R$. (B.) microplus from five dairy herds in northwestern São Paulo.

\section{MATERIAL AND METHODS}

From A pril 2007 to February 2008, five dairy farms were visited in the northwestern region of São Paulo State near São José do Rio Preto City. Four farms located in the municipality of Bady Bassitt (latitude $20^{\circ} 55^{\prime} 05^{\prime \prime}$ south, longitude $49^{\circ} 26^{\prime} 43^{\prime \prime}$ west and $510 \mathrm{~m}$ altitude) and one in Ipiguá (latitude 20 $39^{\prime} 24^{\prime \prime}$ south, longitude $49^{\circ} 23^{\prime} 14^{\prime \prime}$ west and 508 m altitude). In each farm, a questionnaire was applied about productive characteristics and practices of tick control, and at least 200 engorged female ticks of $R$. microplus were manually collected directly from naturally infected cattle. The collecting ticks was done at least 30 days after the last acaricide application on the property.

The properties were small areas with low milk production, which was the main economic activity for all of them.

Collected ticks were placed in perforated plastic containers and sent immediately to Instituto Biológico's Laboratory of Animal Parasitology, where they were tested by adult immersion test according to DRuMmond et al. (1973) modified technique.

Groups of ten healthy females were weighed and immersed into six different acaricide products for 5 minutes, with the exception of cypermethrin, where they were immersed for 10 minutes (Mendes et al., 2000). The acaricides were diluted as recommended by manufacturers. The following principles were tested: amitraz $0.25 \mathrm{mg} / \mathrm{mL}$, deltamethrin $0.025 \mathrm{mg} / \mathrm{mL}$, cypermethrin 0.15 $\mathrm{mg} / \mathrm{mL}$, association chlorpyrifos $0.83 \mathrm{mg} / \mathrm{mL}$ and cypermethrin $0.1 \mathrm{mg} / \mathrm{mL}$, association dichlorvos $1.125 \mathrm{mg} / \mathrm{mL}$ and cypermethrin $0.125 \mathrm{~mL} \mathrm{mg} /$ $\mathrm{mL}$, and association dichlorvos $1.5 \mathrm{mg} / \mathrm{mL}$ and chlorpyrifos $0.5 \mathrm{mg} / \mathrm{mL}$. One group was used as control and immersed in distilled water. Each group, including the control, was subjected to one repetition. After immersion, the females were dried on absorbent paper, placed in Petri dishes and incubated in BOD (biochemical oxygen demand) incubator at $28^{\circ} \mathrm{C}$ and relative humidity of $80 \%$ for 2 weeks to perform the posture. Then the eggs were weighed, transferred to test tubes and incubated under the same conditions for 2 weeks for larval eclosion. The hatched eggs were counted to determine the percentage of hatching.

The efficacy of the treatments was evaluated by calculating the estimated reproduction (ER) and efficacy of the product (EP), according to the formulas (DRUMMOND et al., 1973):

$$
\mathrm{ER}=\frac{\text { egg weight }}{\text { engorged female weight }} \mathrm{x} \% \text { hatching } \times 20,000
$$


$\mathrm{EP}=\frac{\mathrm{ER} \text { of control group }- \text { ER of treated group }}{\text { ER of control group }} \times 100$

Theefficacy of the product was considered optimal when the percentage was higher than or equal to $95 \%$, according to the criteria of Ordinance No. 48 of 1997 determining the conditions for licensing of antiparasitic products (BRASIL, 1997).

The average efficacies for each active ingredient were compared by paired t-test using Minitab 4.0 software and assuming a confidence level of $5 \%$ $(P<0.05)$.

\section{RESULTS}

Thefrequencies of responses to the questionnaire in the five properties are shown in Table 1 . All properties had less than 22 hectares, were intended for the production of milk and raised animals with some degree of Holstein blood. Most of the farms (60\%) had less than 50 head of cattle in the herd and $80 \%$ were using only family labor. The daily milk production was under $100 \mathrm{~L}$ in two properties, while in the other three, it was between 100 and 400 liters. All farms performed rotational grazing, and 40\% (2/5) had irrigation system.

Table 1 - Frequencies of answers to the questionnaire applied in five dairy cattle farms in northwestern São Paulo State, Brazil, 2009.

\begin{tabular}{|c|c|c|}
\hline Question & Answers & Frequency of answers \\
\hline Labor & $\begin{array}{l}\text { familiar } \\
\text { employee }\end{array}$ & $\begin{array}{l}80 \%(4 / 5) \\
20 \%(1 / 5)\end{array}$ \\
\hline Size of the property & $\begin{array}{l}\text { less than } 10 \text { ha } \\
10-22 \text { ha }\end{array}$ & $\begin{array}{l}20 \%(1 / 5) \\
80 \%(4 / 5)\end{array}$ \\
\hline Rotational grazing & $\begin{array}{l}\text { yes } \\
\text { no }\end{array}$ & $100 \%(5 / 5)$ \\
\hline Pasture irrigation & $\begin{array}{l}\text { yes } \\
\text { no }\end{array}$ & $\begin{array}{l}40 \%(2 / 5) \\
60 \%(3 / 5)\end{array}$ \\
\hline Number of cattle on the farm & $\begin{array}{l}\text { less than } 50 \\
50-110\end{array}$ & $\begin{array}{l}60 \%(3 / 5) \\
40 \%(2 / 5)\end{array}$ \\
\hline Exploitation & $\begin{array}{l}\text { milk } \\
\text { beef }\end{array}$ & $\begin{array}{c}100 \%(5 / 5) \\
0(0 / 5)\end{array}$ \\
\hline Daily milk production & $\begin{array}{l}\text { less than } 1001 \\
100-4001\end{array}$ & $\begin{array}{l}40 \%(2 / 5) \\
60 \%(3 / 5)\end{array}$ \\
\hline Breed & Holstein blood & $100 \%(5 / 5)$ \\
\hline Period when greater infestation is observed & $\begin{array}{l}\text { summer } \\
\text { other seasons }\end{array}$ & $\begin{array}{c}100 \%(5 / 5) \\
0(0 / 5)\end{array}$ \\
\hline Choice of acaricide & $\begin{array}{l}\text { indication of shopkeeper } \\
\text { indication of other farmers } \\
\text { indication of technician } \\
\text { no criteria }\end{array}$ & $\begin{array}{l}20 \%(1 / 5) \\
20 \%(1 / 5) \\
20 \%(1 / 5) \\
40 \%(2 / 5)\end{array}$ \\
\hline Frequency of acaricide application & $\begin{array}{l}\text { every } 15 \text { dias } \\
\text { when animals are infested }\end{array}$ & $\begin{array}{l}20 \%(1 / 5) \\
80 \%(4 / 5)\end{array}$ \\
\hline Treated animals & $\begin{array}{l}\text { applies to all animals of the herd } \\
\text { applies only in the most infested animals }\end{array}$ & $\begin{array}{l}80 \%(4 / 5) \\
20 \%(1 / 5)\end{array}$ \\
\hline Application method & $\begin{array}{l}\text { backpack pump } \\
\text { injectable product } \\
\text { pour on }\end{array}$ & $\begin{array}{l}100 \%(5 / 5) \\
80 \%(4 / 5) \\
60 \%(3 / 5)\end{array}$ \\
\hline \multirow{7}{*}{ Chemicals already used } & $\begin{array}{l}\text { bathes the whole body of the animal } \\
\text { bathes only the more infested body sites }\end{array}$ & $\begin{array}{l}80 \%(4 / 5) \\
20 \%(1 / 5)\end{array}$ \\
\hline & $\begin{array}{l}\text { formamidine } \\
\text { amitraz }\end{array}$ & $\begin{array}{l}40 \%(2 / 5) \\
40 \%(2 / 5)\end{array}$ \\
\hline & $\begin{array}{l}\text { pyrethroids } \\
\text { cypermethrin } \\
\text { deltamethrin }\end{array}$ & $\begin{array}{c}100 \%(5 / 5) \\
100 \%(5 / 5) \\
40 \%(2 / 5)\end{array}$ \\
\hline & $\begin{array}{l}\text { organophosphate/organophosphate association } \\
\text { dichlorvos/chlorfenvinphos } \\
\text { dichlorvos/chlorpyrifos }\end{array}$ & $\begin{array}{l}20 \%(1 / 5) \\
20 \%(1 / 5) \\
20 \%(1 / 5)\end{array}$ \\
\hline & $\begin{array}{l}\text { organophosphate/pyrethroid association } \\
\text { chlorpyrifos/cypermethrin }\end{array}$ & $\begin{array}{l}80 \%(4 / 5) \\
80 \%(4 / 5)\end{array}$ \\
\hline & $\begin{array}{l}\text { avermectins } \\
\text { ivermectin } \\
\text { abamectin }\end{array}$ & $\begin{array}{l}80 \%(4 / 5) \\
60 \%(3 / 5) \\
20 \%(1 / 5)\end{array}$ \\
\hline & $\begin{array}{l}\text { growth inhibitors } \\
\text { diflubenzuron }\end{array}$ & $\begin{array}{l}20 \%(1 / 5) \\
20 \%(1 / 5)\end{array}$ \\
\hline Chemical most recently used & $\begin{array}{l}\text { cypermethrin } \\
\text { dichlorvos / chlorpyrifos } \\
\text { chlorpyrifos / cypermethrin }\end{array}$ & $\begin{array}{l}40 \%(2 / 5) \\
20 \%(1 / 5) \\
40 \%(2 / 5)\end{array}$ \\
\hline Knowledge of the adult immersion test & $\begin{array}{l}\text { no } \\
\text { yes }\end{array}$ & $\begin{array}{c}100 \%(5 / 5) \\
0(0 / 5)\end{array}$ \\
\hline
\end{tabular}


Table 2 - Efficacies of six acaricides on Rhipicephalus (Boophilus) microplus ticks in five dairy herds in northeastern São Paulo state, by adult immersion test, Brazil, 2009.

\begin{tabular}{lcccccc}
\hline Property/ & \multicolumn{5}{c}{ Efficacy of chemical (\%) } \\
\cline { 2 - 7 } Municipality & amitraz & cypermethrin & deltamethrin & $\begin{array}{c}\text { chlorpyrifos }+ \\
\text { cypermethrin }\end{array}$ & $\begin{array}{c}\text { dichlorvos + } \\
\text { cypermethrin }\end{array}$ & $\begin{array}{c}\text { chlorpyrifos } \\
+ \text { dichlorvos }\end{array}$ \\
\hline 1 - Bady Bassitt & 93.21 & 25.72 & 24.54 & 88.56 & 58.42 & 52.62 \\
2 - Bady Bassitt & 76.28 & 1.71 & 5.31 & 77.24 & 77.66 & 98.38 \\
3 - Bady Bassitt & 96.59 & 20.15 & 56.64 & 100 & 97.64 & 100 \\
4 - Bady Bassitt & 50.25 & 20.43 & 24.43 & 100 & 79.86 \\
5 - Ipiguá & 45.28 & 18.90 & 22.11 & 28.77 & 19.42 & 48.72 \\
Mean & $73.32^{\mathrm{a}}$ & $17.38^{\mathrm{b}^{*}}$ & $26.61^{\mathrm{b}^{*}}$ & $78,91^{\mathrm{a}}$ & $63.28^{\mathrm{a}^{*}}$ & $75.92^{\mathrm{a}}$ \\
\hline
\end{tabular}

Means followed by different letters were statistically significant $(P<0.05)$, except for $a^{*}$ and $b^{*}$, which showed no difference.

Farmers observed higher infestation by ticks in the summer for all properties. Choosing an acaricide was at random in two properties $(40 \%)$, while the indication by shopkeeper, other farmers and technicians corresponded at $20 \%(1 / 5)$ of the answers each. In most of the properties $(80 \%)$ the application of acaricide was made after viewing the ticks, and in one property it was held every 15 days. In $80 \%$ of the farms, acaricide treatment was done on all animals in the herd, and in $20 \%$, the treatment was done only on those considered most infested. All five properties applied acaricides with manual spray pump, four $(80 \%)$ also used injectable products and three $(60 \%)$ used pour on products. Bathing the entire body of the animal was the sprinkling method used in $80 \%$ $(4 / 5)$ of the properties, but $20 \%(1 / 5)$ bathed only the more infested body parts.

Among the active principle already used by farmers, cypermethrin was cited by $100 \%$ of them, the chlorpyrifos/cypermethrin association was cited by $80 \%$, ivermectin by $60 \%$ and deltamethrin and amitraz by $40 \%$. Abamectin, diflubenzuron and the dichlorvos/chlorfenvinphos and dichlorvos/ chlorpyrifos associations were less commonly reported with $20 \%$ each. When asked about the active principles currently used (last chemical applied before theinterview), cypermethrinand chlorpyrifos/ cypermethrin association were cited by $40 \%(2 / 5)$ of the producers, and dichlorvos/chlorpyrifos by $20 \%(1 / 5)$. None of the farmers knew the adult immersion test or existence of any laboratory method to estimate the efficacy of the product.

The property 4 could not be tested for dichlorvos/ cypermethrin due to lack of sufficient ticks; the other five acaricides were tested.

The pyrethroids cypermethrin and deltamethrin did not obtain satisfactory efficacy percentages in any farm. Amitraz and the organophosphate/ pyrethroid (dichlorvos/cypermethrin) association showed good efficacy in only one property, while another combination of pyrethroid and organophosphate (chlorpyrifos/cypermethrin) and an association of two organophosphates (chlorpyrifos/dichlorvos) demonstrated desirable efficacy in two properties. The average efficiency for cypermethrin and deltamethrin showed statistically significant differences compared to the averages for amitraz, chlorpyrifos / cypermethrin and chlorpyrifos/dichlorvos (Table2).

Two farms (40\%) did not have tick population satisfactorily susceptible to any of the products tested, two (40\%) showed ticks susceptible to two acaricides, and one (20\%) had ticks susceptible to four products (Table 3 ).

Table3-Frequency of herds when active principles showed efficacy lower than $95 \%$ on dairy cattle ticks from five properties in northeastern São Paulo state, Brazil, 2009.

\begin{tabular}{lc}
\hline Chemical & $\begin{array}{c}\% \text { herds with resistant } \\
\text { ticks (efficacy <95\%) }\end{array}$ \\
\hline amitraz & $80(4 / 5)$ \\
cypermethrin & $100(5 / 5)$ \\
deltamethrin & $100(5 / 5)$ \\
chlorpyrifos + cypermethrin & $60(3 / 5)$ \\
dichlorvos + cypermethrin & $75(3 / 4)$ \\
chlorpyrifos + dichlorvos & $60(3 / 5)$ \\
\hline
\end{tabular}

\section{DISCUSSION}

Pyrethroids showed the worst average efficacies (17.38\% to cypermethrin and $26.61 \%$ to deltamethrin), and was the only chemical group that resistance was present in all properties. Works in other regions also had low levels of efficacy for this class of acaricide. MeNDEs et al. (2001) observed an average efficacy for pyrethroids slightly higher $(42.18 \%)$ in the same region of the present study (São José do Rio Preto region), and $33.4 \%$ of efficacy level in São Paulo state, similar to average efficacy for cypermethrin observed by Pereira (2006) in Vale do Paraíba, SP (31.10\%), and by LeITE et al. (1995) in Minas Gerais and Bahia (31.97\%). ARANTES et al. (1995) and CAMILLO et al. (2009) reported $41.74 \%$ and $44 \%$ of efficiencies for cypermethrin respectively in Uberlândia (MG) and in Rio Grande do Sul. As for deltamethrin, 
Pereira (2006) reported efficacy of $25.39 \%$ in Vale do Paraíba, similar to our work, and ARANTES etal. (1995) reported in Uberlândia $45.66 \%$. In Minas Gerais and Bahia, LeITE et al. (1995) detected 51.65\% of efficacy level for deltamethrin. Elsewhere, the averages were higher. In northern Paraná average for deltamethrin was 74.58\% (MERLINI; YAMAMURA, 1998) and in Ilhéus, BA, was 65.04\% (CAMpos Junior; Oliveira, 2005). The high prevalence rates of farms with ticks resistant to pyrethroids have been found in other countries such as Mexico (RodríGuEz-VIVAs et al., 2006a), Australia (Jonsson et al., 2000) and New Caledonia (BIANCHI et al., 2003). The emergence and spread of resistance to pyrethroids occur faster than organophosphate and amitraz (FoIL et al., 2004). JoNSSON et al. (2000) observed that the use of pyrethroids for fly control can increase the risk of resistance, but this issue was not raised in the questionnaire of the present study.

The average efficacy of amitraz in this study $(73.32 \%)$ was slightly lower than observed in the same region $(81.42 \%)$ and in São Paulo state $(86.19 \%)$ by Mendes et al. (2001), in Minas Gerais and Bahia (80.01\%) by Lerte etal. (1995), in Uberlândia (86.53\%) by ARANTES et al. (1995), in the south of Rio Grande do Sul (92\%) by FARIAS et al. (2008) and in northern Paraná (93.51\%) by MerLINI; YAMAMURA (1998). Lower levels, however, were reported by PEREIRA (2006), Campos Junior.; Oliveira (2005) and Camillo et al. (2009), in Vale do Paraíba (47.19\%), in Ilhéus, BA (30.95\%) and in RioGrandedoSul(48.3\%), respectively. The resistance to amitraz seems to spread slower compared to the pyrethroids resistance, even after years of use (JonssON et al., 2000), reflecting in the levels of resistance. In Mexico the prevalence of $19.4 \%$ of properties with ticks resistant to amitraz was detected (Rodríguez-Vivas et al., 2006b) and in Australia, the prevalence was $10.3 \%$ (Jonsson et al., 2000), both values lower than the prevalence of resistance to pyrethroids, also observed in this work.

On the associations of organophosphate and pyrethroid, thecompound chlorpyrifos/cypermethrin showed an average efficacy (78.91\%) higher than dichlorvos/cypermethrin (63.29\%). Similar results for chlorpyrifos/cypermethrin werefound by PEREIRA (2006) in Vale do Paraíba (88.98\%) and by Camillo et al. (2009) in Rio Grande do Sul (80.8\%). The average dichlorvos/cypermethrin efficacy observed by ARANTES et al. (1995) in Uberlândia (70.16\%) and CAmpos Junior.; Oliveira (2005) in Ilhéus (75.73\%) were slightly higher than those found in this study, but LeITE et al. (1995) showed similar level (65.44\%) in Minas Gerais and Bahia.

The association of two organophosphates (chlorpyrifos/dichlorvos) had an average efficacy of $75.92 \%$, similar to the average of $79.29 \%$ to coumaphos found by Mendes et al. (2001) in the same region and below the average of $96.63 \%$ to chlorfenvinphos/dichlorvos found in Uberlândia (ARANTES et al., 1995) and 92.85\% found in the nineties in Minas Gerais and Bahia (LeITE etal., 1995).

In all properties the herd had varied degrees of Holstein blood, common in dairy cattle. The taurine breeds are naturally more susceptible to tick parasitism than zebuine breeds, and this susceptibility increases with the degree of European blood of the animal (SANTOS JUNIOR et al., 2000).

All farmers reported greater infestation in the summer, which is consistent with the observations madeby FARIASetal. (1995) in Araçatuba, a municipality near the area of this study and with similar climate. Thehigher temperatures and rainfall inspring, summer and autumn favor free-living stage of ticks and allow the occurrence of four generations per year (FARIAS et al., 1995; PEREIRA et al., 2008).

The rotational grazing was performed on all properties in order to make better use of grass. However, to aid ticks control, the pasture should remain at least 60 days resting, which does not occur in the usual rotation schedules (Pereira et al., 2008; SANTOS JUNIOR et al., 2000).

Thechoice of acaricidewas madewithoutlaboratory testings, through the suggestion of shopkeepers, other farmers, technicians, or even randomly. No farmer was using or had knowledge of laboratory tests to detect ticks resistance to acaricides. The strategy for tick control was performed without technical criteria, disregarding the parasite populationdynamics, with applications being made irregularly according to visual assessment of the level of infestation, or regularly with high frequency throughout the year. The same observations were made in Passos, MG (Rocha etal., 2006), Rio de Janeiro (SANTOS Junior etal., 2000) and Australia (JonsSON; MATsCHOSS, 1998). The influence of the quality and frequency of treatments on the rate of emergence of resistance is not yet well understood (PEREIRA et al., 2008), but it is generally accepted that a large number of treatments results in an earlier development of resistance (JoNSSON et al., 2000). JoNSSON et al. (2000) observed an association between the resistance to amitraz and more than eight applications of acaricide per year. The same authors found an association between resistance to pyrethroids, acaricidal use more than 5 times a year and regular treatment with more than three weeks interval; on the other hand, irregular applications increased the probability of resistance to flumethrin. RODRíGUEZ-VIVASetal. (2006a) alsofound an association between the resistance to pyrethroids and more than 5 applications per year.

All farmers used manual backpack pump for the application of acaricides in liquid formulation. There is a disagreement about the influence of the type of equipment in the development of resistance to acaricides. Somestudies observed a higher prevalence 
of resistance to chemicals used on properties that utilized spray race compared to manual spray (BIANCHI et al., 2003; JonssON et al., 2000), while in others the manual application increased the risk of resistance (SPICKETT; FIVAZ, 1992). However, other factors related to quality of application, such as equipment conditions, dilution, amount administered, and agitation can accelerate the process of resistance and lead to failures in the control of ticks (GEORGE, 2000).

The principles most used were the pyrethroids, followed by the organophosphate/pyrethroid association and macrocyclic lactones, which reflected in low levels of efficacy found for pyrethroids. Surveys conducted in other regions, however, showed that amitraz is the main principle used, as in Passos, MG (Rocha etal., 2006), south of the RS(FARIAS et al., 2008) and Australia (Jonsson; MATCHOSs, 1998). In these places, pyrethroids, organophosphate/ pyrethroid association and macrocyclic lactones appear after amitraz in the preference of producers. In the present study, however, amitraz is cited by only $40 \%$ of producers, while the frequency of properties in which the principle has not reached the minimum efficacy was $80 \%$. This discrepancy could be explained by possible memory bias when answering to the questionnaire, or the entry of animals on the property already parasitized by ticks resistant to amitraz that reproduced on the property. It was found that some farmers used macrocyclic lactones and growth inhibitors, products not recommended for lactating cattle (JoNSSON; MATSCHOSS, 1998).

Given the widespread resistance, the use of adult immersion test as a criterion for choosing an acaricide should be encouraged among farmers as well as the rational application of chemicals, considering the ecology and tick population dynamics and the correct dilution and application of medications. In addition, other methods should be evaluated for use in association with chemical control, such as the selection of breeds or individuals resistant to parasites, quarantine and vaccination (GEORGE, 2000; Pereira et al., 2008). It is necessary also a constant monitoring of tick resistance to chemicals.

Comparison with other studies should be done with caution, because in this survey few farms were visited, and they do not statistically represent the number of properties in the region. Other works covering bigger areas and larger number of properties are needed to better characterize the situation of resistance in the region.

\section{CONCLUSIONS}

Considering only the averages of the farms, no tested active ingredient showed sufficient efficacy, and pyrethroids had the lowest values, while amitraz and the associations chlorpyrifos/cypermethrin and chlorpyrifos/dichlorvos had the highest average efficacies.

The farmers did not know adult immersion test and administered acaricides disregarding the biological and ecological characteristics of ticks.

The results show the need for guidance to producers on the use of adult immersion test, chemical control strategy, the correct use of acaricides and the use of non-chemical ways to control ticks, in addition to regular monitoring of resistant ticks.

Further studies are needed to better understand the situation of resistance in the region.

\section{ACKNOWLEDGEMENTS}

To FAPESP, for financial support (Process No. 2006/55934-4), and to the farmers who participated in the survey.

\section{REFERENCES}

ARANTES, G.J.; MARQUES, A.O.; HONER, M.R. O carrapato do bovino, Boophilus microplus, no município de Uberlândia, MG: análise da sua resistência contra carrapaticidas comerciais. Revista Brasileira de Parasitologia Veterinária, v.4, n.2, p.89-93, 1995.

BIANCHI, M.W.; BARRÉ, N.; MESSAD, S. Factors related to cattle infestation level and resistance to acaricides in Boophilus microplus tick populations in New Caledonia. Veterinary Parasitology, v.112, n.1/2, p.75-89, 2003.

BRASIL. Ministério da Agricultura, Pecuária e Abastecimento. Portaria $n^{\circ} 48$, de 12 de maio de 1997. Aprova como anexo o Regulamento Técnico a ser observado na produção, no controle e no emprego de anti parasitários de uso veterinário. Disponível em: $<$ http://extranet.agricultura.gov.br/sislegis/action/ detalhaAto.do? method=gravarAtoPDF\&tipo $=P O R \& n$ umeroA to $=00000048 \&$ seqA to $=000 \&$ valor $A n o=1997 \&$ o rgao $=\mathrm{SDA} / \mathrm{MAPA} \& \operatorname{codTipo}=\&$ desItem $=\&$ seqNota $=>$. Acesso em: 1 jun. 2010.

CAMILLO, G.; VOGEL, F.F.; SANGIONI, L.A.; CADORE, G.C.; FERRARI, R. Eficiência in vitro de acaricidas sobre carrapatos de bovinos no Estado do Rio Grande do Sul, Brasil. Ciência Rural, v.39, n.2, p.490-495, 2009.

CAMPOS JUNIOR, D.A.; OLIVEIRA, P.R. Avaliação in vitro da eficácia de acaricidas sobre Boophilus microplus (Canestrini, 1887) (Acari: Ixodidadae) de bovinos no município de Ilhéus, Bahia, Brasil. Ciência Rural, v.35, n.6, p.1386-1392, 2005.

DRUMMOND, R.O.; ERNST, S.E.; TREVINO, J.L.; GLADNEY, W.J.; GRAHAM, O.H. Boophilus annulatus and B. microplus: laboratory tests of insecticides. 
Journal of Economic Entomology, v.66, n.1, p.130-133, 1973.

FARIAS, N.A.; RUAS, J.L.; SANTOS, T.R.B. dos Análise da eficácia de acaricidas sobre o carrapato Boophilus microplus, durante a última década, na região sul do Rio Grande do Sul. Ciência Rural, v.38, n.6, p.1700-1704, 2008.

FARIAS, N.A.; STOBBE, N.S.; CHRISTOVÃO, M.L.; PERRI, S.H.V.; COSTA, A.J. Influência das condições climáticas da região noroeste do Estado de São Paulo, Brasil, sobre os estágios não-parasitários do carrapato Boophilus microplus (Canestrini, 1887) (Acari: Ixodidae). Revista Brasileira de Parasitologia Veterinária, v.4, n.2, p.67-77, 1995.

FOIL, L.D.; COLEMAN, P.; EISLER, M.; FRAGOSOSANCHEZ, H.; GARCIA-VAZQUEZ, Z.; GUERRERO, F.D.; JONSSON, N.N.; LANGSTAFF, I.G.; LI, A.Y.; MACHILA, N.; MILLER, R.J.; MORTON, J.; PRUETT, J.H.; TORR, S. Factors that influence the prevalence of acaricide resistance and tick-borne diseases. Veterinary Parasitology, v.125, n.1/2, p.163-181, 2004.

GEORGE, J.E. Present and future technologies for tick control. Annals of the New York Academy of Sciences, v.916, p.583-588, 2000.

GRISI, L.; MASSARD, C.L.; MOYA BORJA, G.E.; PEREIRA, J.B. Impacto econômico das principais ectoparasitoses em bovinos no Brasil. A Hora Veterinária, v.125, p.8-10, 2002.

JONSSON, N.N.; MATSCHOSS, A.L. Attitudes and practices of Queensland dairy farms to the control of the cattle tick, Boophilus microplus. Australian Veterinary Journal, v.76, n.11, p.746-751, 1998.

JONSSON, N.N.; MAYER, D.G.; GREEN, P.E. Possible risk factors on Queensland dairy farms for acaricide resistance in cattle tick (Boophilus microplus). Veterinary Parasitology, v.88, n.1/2, p.79-92, 2000.

LEAL, A.T.; FREITAS, D.R.J.; VAZ JUNIOR, I.S. Perspectivas para o controle do carrapato bovino. Acta Scientiae Veterinariae, v.31, n.1, p.1-11, 2003.

LEITE, R.C.; LABRUNA, M.B.; OLIVEIRA, P.R.; MONTEIRO, A.M.F.; CAETANO JÚNIOR, J. In vitro susceptibility of engorged females from different populations of Boophilus microplus to commercial acaricides. Revista Brasileira de Parasitologia Veterinária, v.4, n.2, p.283-294, 1995. Suplemento 1.

MENDES, M.C., OLIVEIRA, O.R., VIEIRA-BRESSAN, M.C.R. Determination of minimal immersion times for use in in vitro resistance tests with Boophilus microplus (Canestrini, 1887) engorged females and pyrethroid acaricides. Revista Brasileira de Parasitologia Veterinária, v.9, n.1, p.33-39, 2000.

MENDES, M.C.; VERÍSSIMO, C.J.; KANETO, C.N.; PEREIRA, J.R. Bioassays for measuring the acaricides susceptibility of cattle tick Boophilus microplus (Canestrini, 1887) in São Paulo state, Brazil. Arquivos do Instituto Biológico, São Paulo, v.68, n.2, p.23-27, 2001.

MERLINI, L.S.; YAMAMURA, M.H. Estudo in vitro da resistência de Boophilus microplus a carrapaticidas na pecuária leiteira do norte do Estado do Paraná. Semina: Ciências Agrárias, v.19, n.1, p.38-44, 1998.

PEREIRA, J.R. Eficácia in vitro de formulações comerciais de carrapaticidas em teleóginas de Boophilus microplus coletadas de bovinos leiteiros do Vale do Paraíba, Estado de São Paulo. Revista Brasileira de Parasitologia Veterinária, v.15, n.2, p.45-48, 2006.

PEREIRA, M.C.; LABRUNA, M.B.; SZABÓ, M.P.J.; KLAFKE, G.M. Rhipicephalus (Boophilus) microplus: biologia, controle e resistência. São Paulo: MedVet, 2008. 169p.

ROCHA, C.M.B.M.; OLIVEIRA, P.R.; LEITE, R.C.; CARDOSO, D.L.; CALIC, S.B.; FURLONG, J. Percepção dos produtores de leite do município de Passos, MG, sobre o carrapato Boophilus microplus (Acari: Ixodidae), 2001. Ciência Rural, v.36, n.4, p.1235-1242, 2006.

RODRIGUEZ-VIVAS, R.I.; ALONSO-DÍAZ, M.A.; RODRÍGUEZ-AREVALO, F.; FRAGOSO-SANCHEZ, H.; SANTAMARIA, V.M.; ROSARIO-CRUZ, R.

Prevalence and potential risk factors for organophosphate and pyrethroid resistance in Boophilus microplus ticks on cattle ranches from the State of Yucatan, Mexico. Veterinary Parasitology, v.136, n.3/4, p.335-342, 2006a.

RODRÍGUEZ-VIVAS, R.I.; RODRÍGUEZ-AREVALO, F.; ALONSO-DÍAZ, M.A.; FRAGOSO-SANCHEZ, H.; SANTAMARIA, V.M.; ROSARIO-CRUZ, R. Prevalence and potential risk factors for amitraz resistance in Boophilus microplus ticks in cattle farms in the State of Yucatan, Mexico. Preventive Veterinary Medicine, v.75, n.3/4, p.280-286, 2006 b.

SANTOS JÚNIOR, J.C.B.; FURLONG, J.; DAEMON, E. Controle do carrapato Boophilus microplus (Acari: Ixodidae) em sistemas de produção de leite da microrregião fisiográfica fluminense do Grande Rio - Rio de Janeiro. Ciência Rural, v.30, n.2, p.305-311, 2000.

SPICKETT, A.M.; FIVAZ, B.H. A survey of cattle tick control practices in the eastern Cape Province of South Africa. Onderstepoort Journal of Veterinary Research, v.59, n.3, p.203-210, 1992.

Received on $10 / 1 / 11$

Accepted on 8/5/12 